\title{
QUALITY OF URBAN PUBLIC TRANSPORT WEBSITES ACCORDING TO EXTENT OF PROVIDED INFORMATION
}

\author{
Josef Bulíček, Pavel Drdla \\ Jan Perner Transport Faculty, University of Pardubice, Pardubice, Czech Republic
}

Submitted 2 October 2013; resubmitted 27 March 2014; accepted 5 January 2015

\begin{abstract}
This paper is based on the analysis of websites of Urban Public Transport (UPT) made in different states. The paper proposes a standard of 'minimal information websites content' named as 'Passenger Friendly Web'. Information content is divided into a set of elements. Their weights are determined by expert evaluation with the support of mathematics, especially of Saaty's Method. Possibilities for future research are also regarded. Results can be applied to all Internet websites of UPT.
\end{abstract}

Keywords: AHP method; customer; information system; mass passenger public transport; respondent survey; quality of passenger carriage.

\section{Introduction}

The increasing role of the Internet sources in the process of searching for transport information by passengers is still in progress. Information of Urban Public Transport (UPT) is not an exception. On the other hand, the extent of information content, as well as the level of graphical solution is quite different between each individual websites of UPT (for different cities).

For practical illustration it is possible to find balanced websites presentations with all required information (also convenient for passengers who are not used to travelling by an UPT system regularly). On the other side, a lot of UPT systems are presented by partial or incomplete information as well. Sometimes passengers are not able to find any information, or there is too much poor information only, that it cannot be considered as a useful one. The worst situations usually occur in cases of small UPT systems, usually operated by buses only, for example, where a connection search engine is often available with no additional information.

Modal share of UPT, especially in comparison with individual car transport, is still decreasing. This negative tendency and appropriate measures for slowdown should be applied. Another measure to be considered is also the minimal accessibility to information via the Internet. It should not be presumed that potential passengers, as well as current UPT passengers will search for information for a long time or that they will accept having missing data necessary for their journeys. The problem is more serious, when passengers are able to use individual car transport as an alternative (and sometimes also as 'their basic transport solution').

It must be said that the supply of UPT is a service provided in the public interest, and that the supply of these services is a part of public obligation. Due to the fact that this service is supported by various public sources and budgets, high utilization of this service by passengers is required.

Important factors that influence a potential passenger's decision on whether or not to use UPT include the quality of information sources, the complexity of the information provided, and the usefulness of the information.

Websites are described as the most important and basic electronic information source. Information provided by other electronic sources (such as various applications for smart phones, information channels based on social networks, etc.) will be derived from the base of these standards that are valid (proposed) for websites. It is then possible, in accordance with the market and communication strategy of the transport company (or other subject responsible for UPT information providing), to implement additional functions such as discussions, and the sharing of videos.

General motivation of this research is able to be stated: 'Internet presentations of UPT are not created at the best quality or with the highest explanatory power possible (with regard to costs and other limitations)'. 
This is valid for all UPT systems without regard to size and the geographical location of the UPT system in the World.

Evaluation of this general presumption is introduced on the end of Chapter 9 - Scoring of Websites.

Final hypothesis, able to be tested, is related to searching time of connection. The hypothesis is: 'Connection searching time is related to information extent in a negative way'. Hypothesis is characterized and tested in Chapter 10 - Hypothesis. Extent of provided information and flexibility of websites using are considered as an essential part of quality.

Naturally the research is focused on the ways to improve the quality and explanatory power of the information provided.

\section{State-of-art Situation}

Information systems, as well as intelligent transport systems, are often a target for research. Basic overviews can be found, for example, in researches carried-out by Kolosz et al. (2013), Crainic et al. (2009), Xu et al. (2013), Vlassenroot et al. (2010), Yatskiv et al. (2013), Monzon et al. (2013) or Tyrinopoulos (2011); however, such works are often focused on the whole structure of a system or on the technical structure of the system.

Assessing the websites, quality is characterized (Hasan, Abuelrub 2010) on the general level for all scopes of websites. Quality of web services is measured in four points of view (categories): content, design, organisation (structure of websites) and user-friendly quality.

This paper and research will follow the first category - content quality in detail and in the frame of UPT.

Quality of information systems is a part of overall assessment of quality of the whole transport process. Information about surveying and modelling of statedpreferences is mentioned in (Dell'Olio et al. 2011).

Importance of 38 information aspects of transport web-based information system is measured in (Molin, Timmermans 2006). This measurement has been made with regard to possibility of paying for this (additional) information.

Information needs by passengers of Dublin public urban transport system are mentioned in (Caulfield, O'Mahony 2007). There is stated that $59 \%$ of survey respondents disagree with the fact that the lack of information can deter them from using public transport. This is valid with some limitations only. First of all, information needs as well as Internet services are developing dynamically in time. Second, an important fact is able to be seen in size of the city. It is able to presuppose that there is a relation between travel distances and willingness to choose UPT without previous information due the practical impossibility to walk for longer distances. Difficult situation is also often occurred in competitive road traffic in the case of big cities.

Analysis of the geospatial content of public transport websites (for 60 locations worldwide) is presented in Morrison (2012). There is stated an important fact that websites of UPT are often not existing in the Third World, developing countries, for country areas and the smallest towns.

It is also confirmed for the examples of the smallest towns (UPT systems) in the Czech Republic and Slovakia in this paper. This can be considered as an important problem. There is no relation between size of city and information needs. On the other hand, the smallest UPT systems must be promoted due the serious competition with walking and individual car transport. Walking distances and problems by car driving are usually minimal in the small towns.

Importance of unification of information channels can be also documented by the EDITS (2013) research project. This project is funded by the European Regional Development Fund and it lasts from 2012 to 2014. The project is led by AustriaTech. The aim is to interconnect existing internet information systems in part of Central Europe. It is focused especially on the technical level of solution.

This paper is focused on the content and meaning of information accessible on websites, the basic electronic information source, with an effort to determine individual elements of information content, whilst proposing ways to standardize transport information quality. Utilization of multi-criteria analysis in transport is mentioned (Mahmoud, Hine 2013) in the field of bus transport demand estimation, but generally describes all aspects of relevant decision-making.

Electronic Service Quality (e-SQ) is highlighted in the paper (Cheng 2011) in the frame of Taiwan highspeed railway system. There is also stated that quality of information services is a challenge and essential tool for attracting passengers. The e-SQ can be a standard for providing electronic information services, but different conditions for fulfilling after object of websites are necessary. Model presented in (Cheng 2011) is oriented on different group of passengers. Passengers of high speed railways are usually planning their journeys for relative long time before. Different model must be developed for UPT. UPT is more frequently used transport system and in a more operative way. Some basic presumptions of e-SQ standard must be also followed.

The internet is a core information channel used for searching transport service information, and will have an increasing role in the future. It is a requirement that quality standards of information publishing, via websites, would be met. For that reason, the providing of information is also included in the European Standard EN 13816:2002 (or ČSN EN 13816:2003) as well as by EN 15140:2006 (or ČSN EN 15140:2007), but on a general level only. Research presented in this paper can be used to form subsequent (internal and external company) legislation measures.

\section{General Timetable Information System}

It was mentioned before that in some cases; only a connection search engine is available. In the case of the Czech Republic and Slovakia, such information is 
provided by the general timetable information system $\operatorname{IDOS}^{\mathrm{TM}}$ (2014), allowing searching of railway, bus, UPT and air transport timetables in the one place (websites). Timetables of so called integrated systems of public passenger transport ('transport associations' in German terminology) are also incorporated. This nation-wide system is operated by a company authorized by the state. Providing of data for the IDOS ${ }^{\mathrm{TM}}$ (2014) system is based on legislation (it is obligatory). The advantage is that it is then possible to find connections at one location that 'cross-over' all transport modes, operators, integrated transport systems or associations. This access (legislative definition) is well-evaluated and useful for international comparison. This is mentioned here as a best-practice example of how an information service can be improved and unified.

On the other hand, local-based information (UPT line scheme, description of fare collecting system, information about opening hours of customer centres, etc.) is not usually incorporated directly into the IDOS $^{\mathrm{TM}}$ system, and for that reason this information is often missing. It is in competence of individual transport operators, coordinators of integrated systems of passenger transport or individual cities as well to be presented individually (on websites).

\section{Start of Research}

The decision has been made to start research of ways in which the quality of information services provided (by websites) can be measured and improved. This decision was made due to criticism of the quality of UPT Internet presentations in different towns and cities.

First of all, it has been discovered that passengers prefer easily accessible information. For instance, graphical solution (design) of websites is not a priority. One of the reasons for this preference is that it takes longer to get information (due to higher volume of data necessary to be downloaded) when displayed with complicated graphic design. The problem is serious, especially cases of slow Internet connections or when downloading data to devices like cellular phones, etc.

This and other facts have been discovered through the analysis of passengers opinions and ideas. The analysis was performed in direct contact (own passenger survey) as well as in indirect contact (e.g. opinions expressed at Internet discussion forums).

Analysis was focused on information services available by websites of individual UPT systems (cities).

Different opinions on the content of published information have been highlighted by passengers. It is dependent on the 'regime' of the passenger searching for data. In this context, UPT passengers are able to be divided into three main groups.

Group 1. Regular travellers with no changes in transport behaviour (e.g. daily commuters) - this group of passengers is characterized by the highest satisfaction with state-of-the-art information content of websites, however, members of this group (passengers preferring regular use of UPT) rarely access these websites.
These passengers know their connections very well, as they are always moving on the same route or routes. They are also well informed about fares and the fare collecting system, as they are often holders of a type of a season ticket. These passengers are usually at stops for a minimal amount of time and they do not search for any information. In the case of operational information, they know very well where to find it.

Group 2. Regular travellers with change of transport behaviour - smaller or small satisfaction with information content of websites presentations. These passengers are not using the same transport relations only. In the case of lack of information, they are able to decide for other transport mode.

It is a group of regular passengers (they can be also daily commuters), but they are using not their regular and well-known connections only. Sometimes they are travelling also on other transport relations, where they have not their own knowledge or overview. It is able to be presupposed that they will search for connection (timetable) as well as for fare information in the case of more complicated fare structure (e.g. in what tariff zone the destination stop is situated). On the other hand, members of this passenger group have basic and general information how the UPT system is organised.

Group 3. Irregular and occasional travellers - very low satisfaction with extent of provided information. City visitors as well as passengers travelling in some seasons only (e.g. in winter period due to bad climatic conditions) are able to illustrate this group of passengers. Criticism is especially oriented on following problems: information is not accessible at one place (in one Internet presentation) only; information extent is unsatisfied or not understandable for passengers without knowledge of local conditions, etc. There is a presumption that the probability of UPT choosing is decreased and UPT will not be used by this group of passengers.

These passengers need maximum extent of information from connection search engine, over network scheme, tariff, fare collecting and check-in systems description to tickets accessibility information. Orientation (e.g. in interchanging terminals) of these passengers can be more difficult and longer due to having no previous knowledge with using of that UPT system. General basic information well-known for regular passengers is often searched as well.

There is often able to be found a simplified presumption that the first group - regular travellers with not so much extended information needs must be taken into account as the first step. Often occurred consequence of this is that information extent can be limited. Regular passengers do not need extended information. Problem will occur in the case that these passengers want to change their routes and demands on provided information can increase. This effect will cause skipping to the second group of passengers. In the case that required information will not be found, a risk of changing to other transport mode (to individual car or to pedestrian transport as well) is occurred. 


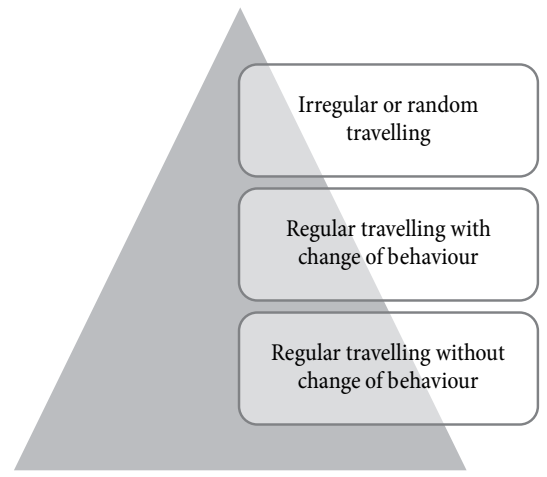

Fig. 1. Groups of passengers in UPT

As follow from the facts mentioned above, passengers of each mentioned group (Fig. 1) are important from the point of view of provided information. It is necessary to take maximal care about all of these groups of passengers. Internet presentations must be well-structured and using of them has to be focused on the most easy, quick and comfortable reaching of required information. For instance, regular passengers (with knowledge of UPT systems) will not spend time due to repeated passing through sets of well-known general information. On the other hand, irregular and occasional passengers must get all necessary information, including all basic and for 'home' passengers well-known information (like scheme of lines, tariff and fare collecting system, etc.).

\section{Practical Survey}

Relatively large survey, focused on information provided by Internet presentations (websites) of UPT systems, has been done for research needs in this field. The aim was to identify a set (structure) of information elements suitable to be used on UPT websites. The best practice and also problematic examples were considered. Determined set (structure) of information elements is used as the basic framework for consequent considerations.

Survey was focused especially on the majority of UPT systems operated in the Czech Republic. There are about 100 cities or towns with UPT system (17 systems with electric-powered subsystem - trams, trolleybuses or underground; the rest is based on buses only). The research is not national only; a lot of UPT systems abroad, especially in Slovakia and German-speaking countries (Germany, Austria, Switzerland) have been taken into this survey as well.

The main and the most general result is that there is a quite different extent of provided information by individual UPT systems. Any of estimated presentations does not fulfil all information demands in the point of view of all three followed groups of passengers.

Survey was focused not only on passengers with common transportation needs, but also on passengers requiring specific information, like passengers with transportation limitations (e.g. with baby prams), language limitations (foreigners), health limitations (disabled people - especially people with visual or motion handicaps). Existence of foreign-language mutations of websites (and also their extent); blind-friendly web modification for people with visual handicaps (Matuška 2010) as well as complexity of information for passengers with limited ability to move (using wheel chairs), were taken into account by the survey. It is able to be pointed out as the best practice case, that providing of specific information to visually impaired people is also adjusted by legislative norm in the Czech Republic.

Results of this survey are mentioned in detail way in Chapters 5-7.

\section{Minimum of Information Provided by Internet Presentations}

It has been found out by this complex survey (mentioned in Chapter 4), that there is a group of important (core) elements of information content of Internet presentations. Missing of these elements is able to be considered as unsatisfying state or as a great mistake. These core elements are:

- basic information about UPT operator (undertakings) and contacts;

- basic information about UPT system and using of them;

- actual information about UPT;

- scheme of lines;

- timetables;

- information about transport irregularities and changes in operation;

- tariff system and complete transport conditions (rules), including information about tariff zones, etc.

\section{Additional Information}

It has been also discovered by the survey, that there is a number of other (additional) information elements. Using of these elements is considered as recommended in spite of ordered or necessary (Chapter 5). Utilizing of additional elements is also depended on size of UPT system as well as on local conditions and specifics. These elements are deeply mentioned in following Chapter 7 in the list of all considered information elements.

\section{Elements of Information Content of Internet Presentations}

There is a mentioned list of all considered elements of information content of Internet presentations in this chapter. Information elements are sorted into 4 main categories marked by letters. Categories are created after scope of content:

- A - Travel Information - information needed for transport process (important for concrete journey);

- B - System Information - fare, fare collection system, barrier-free and night transport (information how to use UPT, necessary especially by first coming to the UPT system); 
- C - Additional System Information - information about UPT for special purposes, e.g. information about ticket inspection, complaints, lost-andfounds, information in foreign languages;

- D - Information for Non-Travel Purposes - information about transport company and UPT system, statistics, information about UPT history, special rides, photo gallery, etc.

Elements are named after categories in order how they are preferred by experts (starting from the most important element). There is also published a brief explanation of element in the case, if the element is specific.

Category A - Travel Information

A1 - Connection search engine - in the form of link to 'general' timetable information system or own connection search engine accessible by websites.

A2 - Information about places of tickets (transport documents) sale - shops, information centres, ticketvending machines, newsstands, etc.

A3 - Information about using of check in/out system or other fare collecting system (especially when it is based on smart cards).

A4 - Interactive map of UTP with details about stops location. Stops are displayed in the map and a window with details about stops (like numbers of lines using stop and link to their timetables) will occur after click on the icon of the stop in the map. Photo of the stop as well as photo map with identification of important objects in surroundings are able to be accessed. GPS position and information about equipment (waiting room, bank, ticketvending machine, UPT information table, text in Braille, QR code for mobile phones, etc.) of each stop are also included. Information about barrierfree accessibility must be also equipped (height of platform edge, surface type, etc.). Best-practice example of interactive map for UPT of Brno is able to be found at (KORDIS JMK, a.s. 2014).

A5 - List of stations and stops + numbers of lines using each stop.

A6 - Important objects and information about the nearest UPT stop.

A7 - List of streets in the city and information about the nearest UPT stop.

A8 - Detailed information about interchanging points in the UPT.

A9 - Plans of important stations and stops incl. their surroundings.

Category B - System Information

B1 - Information about free-of-charge transport in UPT.

B2 - Information about all types (patterns) of tickets.

B3 - Information about UPT reachable by cellular phones and devices (e.g. simplified version of websites for cellular phones).

B4 - Information about transport of disabled/handicapped people.

B5 - Information about night UPT operation.

B6 - Simplified excerption from the complete transport rules.
B7 - Travelling tips (where and how to travel - airport, zoo, etc.).

B8 - Information about information and customer centres of UPT system.

B9 - Information about Park and Ride, Bike and Ride and Kiss and Ride systems.

Category C - Additional System Information

$\mathrm{C} 1$ - Information about UPT in foreign languages (foreign language mutations).

C2 - Lost-and-found (what is the process).

C3 - Information about ticket inspection, authority of ticket inspectors.

C4 - Information about planned changes in UPT in the future.

C5 - Frequently Asked Questions (FAQ) and answers.

C6 - Process by complaints.

C7 - Press Releases and reports about UPT in press.

C8 - Possibility of sending of actual information by cellular phones.

C9 - UPT discussion forum.

Category D - Information for Non-Travel Purposes

D1 - Points of interest in UPT.

D2 - Surveys and quizzes.

D3 - Statistical numbers about UPT (length of network, number of vehicles, transport outputs, etc.).

D4 - UPT photo gallery.

D5 - Newspaper (journal) about UPT (issued by UPT operator) to be downloaded.

D6 - UPT history.

D7 - Information about sale of UPT souvenirs.

D8 - Information about possibility of extra drives (possibility of historic vehicles).

These elements of the Internet presentation (35 in total) are perceived with various level of importance by passengers. Different elements are preferred by individual passengers. It is very subjective and complicated to estimate order and subsequently importance (weights) of these elements by their preference in general point of view. Expert analysis combined with some methods has been used for it as it is characterized in Chapter 8 .

\section{Estimation of Preference, Data Processing}

It was very essential to estimate the weights (importance) of all these information elements to be discovered their role and meaning in information process. A group of 59 experts was asked to compare (evaluate) those 35 elements as well as other elements of UPT websites in the autumn of the year 2012. Scale of 9 points compatible with Saaty's Method was used for this comparison (Saaty, Vargas 2013; Saaty 1980).

Some examples of each information element from different websites presentations of UPT (from different UPT systems) were accessible, so that experts had detailed information about meaning, function and content of each individual element.

Finally basic principles of Saaty's Method (known also as AHP - the Analytical Hierarchy Process) were used for evaluation of preference level. Relations between all pairs of information elements were evaluated by the scale of 1-9 points from equal position of elements 
(1 point) to absolute preference of element $i$ in row to element $j$ in column of the Saaty's Matrix (9 points). In the case that element $i$ in row is not preferred to element in column, reciprocal value of $s_{i j}=1 / s_{j i}$ is used.

Saaty's Method was used in two-level process. 35 information elements are sorted in 4 categories (A, B, C, D). They are introduced in Chapter 7. These categories create the first level. Weights of individual categories were estimated as: A - 0.6207, B - 0.2069, C - 0.1034 and $\mathrm{D}-0.0690$.

The second level was made for each individual category. Weights of individual information elements were estimated in the frame of each category. In total there are 4 Saaty's matrices with 9, 9, 9 and 8 elements for each category.

Final weights of information elements (Table 1) are calculated as the product of category weight and weight of each individual information element (in the category).

All five Saaty's matrices are consistent. The maximal Consistency Index CI (for matrix in category A) is equal to 0.053 . Limit of consistency (critical value) is 0.10 . This presumption is following from original Saaty's procedure as recommendation. The way of calculation of $C I$ is mentioned in the Sub-Chapter 8.3.

The values $s_{i j}$, respectively $1 / s_{j i}$ has been set by all 59 asked experts. Resulting values used in final Saaty's matrices are averages of original values after replacing of extreme values for reduction of statistical deviation.

This procedure has been elaborated for all 595 compared pairs of information elements (comparisons on the main diagonal of the matrix were set to value of 1 automatically - one element is not able to be preferred to the same own element).

Information elements have been sorted by help of Fuller's Method results. The final shape of the Saaty's matrices representing pairwise comparisons is that the values $s_{i j}>1$ for preferred elements in rows are sorted upon the main diagonal, the values $s_{i j}<1$, where $s_{i j}=$ $1 / s_{j i}$ for preferred elements in columns are under the main diagonal. This sorting is not obligatory from the mathematical point of view. It is done for presentation purposes.

Estimation of weights $w_{i}$ of individual elements of Internet presentations has been determined parallel by utilizing of three methods - Method of Order, Fuller's Method and Saaty's Method (Ragsdale 2011). Calculations by Method of Order and Fuller's Method have been done for help, control and comparison purposes. The main focus is put on solution reached by Saaty's Method.

Results reached by all methods have been compared and they all are mentioned in the Table 1.

As follows from the Table 1 the best results for practical use are provided by Saaty's Method (all used methods are characterized in Sub-Chapters 8.1-8.3). These results (Saaty's Method) have been declared as basic and decisive order of importance.

There are also some other methods how to estimate weights of elements (criterions), but they have not been utilized due to reduction of demands put on experts (to write down other additional data) by input estimation (survey).
Table 1. Estimation of weights of elements of Internet presentations in the way of different methods; final order determined by Saaty's Method (AHP)

\begin{tabular}{|c|c|c|c|c|}
\hline 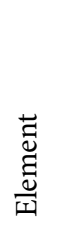 & 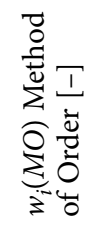 & 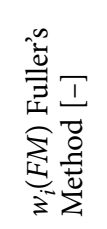 & 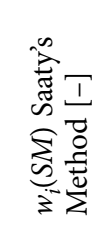 & 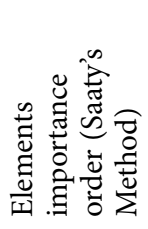 \\
\hline A1 & 0.0556 & 0.0571 & 0.1632 & 1 \\
\hline A2 & 0.0540 & 0.0555 & 0.0767 & 4 \\
\hline A3 & 0.0524 & 0.0538 & 0.0804 & 3 \\
\hline A4 & 0.0508 & 0.0521 & 0.0930 & 2 \\
\hline A5 & 0.0492 & 0.0504 & 0.0593 & 5 \\
\hline A6 & 0.0476 & 0.0487 & 0.0497 & 6 \\
\hline A7 & 0.0460 & 0.0471 & 0.0399 & 8 \\
\hline A 8 & 0.0444 & 0.0454 & 0.0306 & 10 \\
\hline A9 & 0.0429 & 0.0437 & 0.0279 & 12 \\
\hline B1 & 0.0413 & 0.0420 & 0.0345 & 9 \\
\hline B2 & 0.0397 & 0.0403 & 0.0410 & 7 \\
\hline B3 & 0.0381 & 0.0387 & 0.0282 & 11 \\
\hline B4 & 0.0365 & 0.0370 & 0.0225 & 13 \\
\hline B5 & 0.0349 & 0.0353 & 0.0200 & 14 \\
\hline B6 & 0.0333 & 0.0336 & 0.0176 & 16 \\
\hline B7 & 0.0317 & 0.0319 & 0.0141 & 20 \\
\hline B8 & 0.0302 & 0.0303 & 0.0168 & 17 \\
\hline B9 & 0.0286 & 0.0286 & 0.0122 & 23 \\
\hline $\mathrm{C} 1$ & 0.0270 & 0.0269 & 0.0179 & 15 \\
\hline C2 & 0.0254 & 0.0252 & 0.0165 & 18 \\
\hline C3 & 0.0238 & 0.0235 & 0.0149 & 19 \\
\hline $\mathrm{C} 4$ & 0.0222 & 0.0218 & 0.0123 & 22 \\
\hline C5 & 0.0206 & 0.0202 & 0.0112 & 24 \\
\hline C6 & 0.0190 & 0.0185 & 0.0109 & 26 \\
\hline C7 & 0.0175 & 0.0168 & 0.0073 & 30 \\
\hline $\mathrm{C} 8$ & 0.0159 & 0.0151 & 0.0063 & 31 \\
\hline C9 & 0.0143 & 0.0134 & 0.0062 & 33 \\
\hline D1 & 0.0127 & 0.0118 & 0.0131 & 21 \\
\hline D2 & 0.0111 & 0.0101 & 0.0112 & 25 \\
\hline D3 & 0.0095 & 0.0084 & 0.0109 & 27 \\
\hline $\mathrm{D} 4$ & 0.0079 & 0.0067 & 0.0090 & 28 \\
\hline D5 & 0.0063 & 0.0050 & 0.0079 & 29 \\
\hline D6 & 0.0048 & 0.0034 & 0.0063 & 32 \\
\hline D7 & 0.0032 & 0.0017 & 0.0057 & 34 \\
\hline D8 & 0.0016 & 0.0000 & 0.0051 & 35 \\
\hline
\end{tabular}

\subsection{Method of Order}

The Method of Order is able to be interpreted as mathematical formalisation of ordinal information about order of elements after their importance. It is not able to be decided about 'difference' in importance of subsequent elements in order. All differences in importance 
of neighbouring elements are the same (in consonance with order). Estimation of weights is also depended on total number of surveyed elements $n$. The value of $n$ is 35 in this case.

Weight of each individual element of the Internet presentation is estimated by the Eq. (1):

$$
w_{i}(M O)=\frac{n-i+1}{\sum_{i=1}^{n}(n-i+1)}, i=1,2, \ldots, n,
$$

where: $w_{i}(M O)$ - weight of element of information content calculated by the Method of Order [-]; $n-$ number of surveyed elements $(n=35) ; i$ - order of element on importance scale (row number).

\subsection{Fuller's Method}

Fuller's Method is based on the principle of pairwise comparisons of all elements. It is essential to mark more preferred variant in all pairs of elements (595 pairs in this case). Marking is based on mentioned experts' evaluation.

There is unequivocal information about order of information elements and no pair of elements is located on the same level (rank) in the survey. This is basic feature able to be regarded in the Fuller's Method for its simplified calculation. Each element is $(n-i)$-times more important than each other element (in comparison for every pair), where $i$ is order of element on the importance scale and $n$ is number of all elements. Weights calculation is able to be realized in simplified form by Eq. (2):

$$
w_{i}(F M)=\frac{n-i}{\left(\begin{array}{l}
n \\
2
\end{array}\right)}=\frac{n-i}{\frac{n(n-1)}{2}}, i=1,2, \ldots, n,
$$

where: $w_{i}(F M)$ - weight of element of information content calculated by the Fuller's Method [-]; $n$ - number of surveyed elements of information content $(n=35)$; $i$ - order of element on importance scale (row number).

\subsection{Saaty's Method (AHP)}

Saaty's Method also named as AHP (Multi-Criteria Analysis... 2009; Saaty, Vargas 2013) is also based on pairwise comparison of elements, but reflection how compared elements are differing in importance is able to be incorporated.

As it was mentioned before Saaty's Method is based on created square matrix with values of $s_{i j}$ in each individual cell, where $i=1,2, \ldots, n$ and $j=1,2, \ldots n$. Values of $s_{i j}$ are representing the rate of preference how the element $i$ is more important than element $j$.

There are able to be found more different ways of calculation for weights estimation based on the Saaty's Method. These ways are able to be named as: Saaty's procedure using eigenvector matrix; process based on geometric means; process based on arithmetic means; process based on row sums of (modified) Saaty's matrix or process based on reciprocal column sums of Saaty's matrix.
The principle based on geometrical means (averages) was used in this concrete case. It is able to be said that this principle is the most effective in the point of view of equilibrated result accuracy and calculation demands.

The weights (importance level) of elements are able to be reached by Eq. (3):

$$
\begin{gathered}
w_{i}(S M)=\frac{\left(\prod_{j=1}^{n} s_{i j}\right)^{\frac{1}{n}}}{\sum_{i=1}^{n}\left(\left(\prod_{j=1}^{n} s_{i j}\right)^{\frac{1}{n}}\right)}, \\
i=1,2, \ldots, n ; j=1,2, \ldots, n,
\end{gathered}
$$

where: $w_{i}(S M)$ - weight of element of information content calculated by the Saaty's Method; $n$ - number of surveyed elements of information content $(n=35)$; $s_{i j}$ - value in $i$ row and $j$ column of Saaty's matrix; $i$ - row number (index) of Saaty's matrix; $j$ - column number (index) of Saaty's matrix.

Saaty's matrix must be consistent. Following presumption must be fulfilled by the consistent matrix. If the element $K_{2}$ is two times more important than $K_{1}$ and element $K_{3}$ three times more important than $K_{2}$, element $K_{3}$ must be six time more important than $K_{1}$ in the consistent matrix. It is complicated to ensure this simple presumption due to high number of pairwise comparisons as well as due to methodology of determination of preference values (based on survey in this case). Coefficient of consistence $C I$ is able to be used for decision, if the matrix is consistent on acceptable level or not. Consistency index is calculated by Eq. (4):

$$
C I=\frac{\lambda_{\max }-n}{n-1}
$$

where: $\lambda_{\max }$ - eigenvalue of the matrix; $n$ - number of categories or surveyed elements of information content ( $n$ is equal to $4,9,9,9,8$ in individual cases); $C I$ - consistency index.

Eigenvalue of the matrix $\lambda_{\max }$ is able to be calculated by Eq. (5):

$$
\lambda_{\max }=\frac{s_{11} w_{1}+s_{12} w_{2}+\ldots+s_{1 n} w_{n}}{w_{1}}
$$

where: $\lambda_{\max }$ - eigenvalue of the matrix; $s_{i j}$ - values of Saaty's matrix located on positions of $i j ; w_{i}$ - calculated weights of individual Internet presentation elements.

\subsection{Interpretation of Results}

The graph on the Fig. 2 provides information about order of importance of individual elements of Internet presentations reached in the way of Saaty's Method. Connection search engine (A1) is dominant element with weight (importance level) of $16.32 \%$. The explanations to coded marking of elements on the Fig. 2 are located in the Chapter 7 of this paper. Information about 
special journeys (realized by historical vehicles) is located on the last position as the least important element of Internet presentations with the weight of $0.51 \%$. The sum of weights of all considered elements is naturally $100 \%$.

Graph of importance weights reached in the way of the Method of Order is mentioned on the Fig. 3. It will be a good illustrational comparison of difference in calculation methodologies (Method of Order and Saaty's Method).

The mathematical difference between both methods is able to be seen by comparison of both figures. Weights reached in the way of the Method of Order are 'mechanically' determined and the elements have got the same 'difference' in order between each two elements located on neighbouring ranks.

Saaty's Method is able to be used as adequate due to the fact, that this method provides the widest scope of information. It is possible to calculate with different rates of preference between all neighbouring elements on the preference scale. Relation between results reached by all methods has been statistically confirmed (tested) in the way of Wilcoxon test.

Each pair of results was compared, all are depended. The values of criterion $W$ are: for the pair Method of Order - Fuller's Method $W=315$, for the pair Method of Order - Saaty's Method $W=211$ and for the pair
Fuller's Method - Saaty's Method $W=207$. Critical value for rejecting of hypothesis that the values are not related is $W_{\text {critical }}=195.3$ for this case $(n=35)$. Hypothesis is rejected if value of $W$ is over $W_{\text {critical }}$.

Results are depended also in this case, where there different calculating principles have been used. For that reason, it is not necessary to find more accurate ways of calculation with increased calculating demands (like original Saaty's principle) to replace this access based on Saaty's Method and geometrical averaging.

\section{Scoring of Websites}

UPT websites of 32 cities and towns in the Czech Republic and Slovakia as well as of 129 cities abroad (in the whole World) were taken into extended consideration and scored by estimated weights of individual information elements. Websites of whole UPT system (transport operator) were taken into consideration. In the case that there is not complex websites for whole UPT system at disposal, websites of major transport operator or dominant subsystem of UPT (especially underground) has been scored. Towns and cities are divided into 5 categories after numbers of inhabitants. Basic overview is provided by Table 2 and box graphs on Fig. 4. Detail information about scoring of individual cities is provided by Tables A1-A5 (located in Appendix).

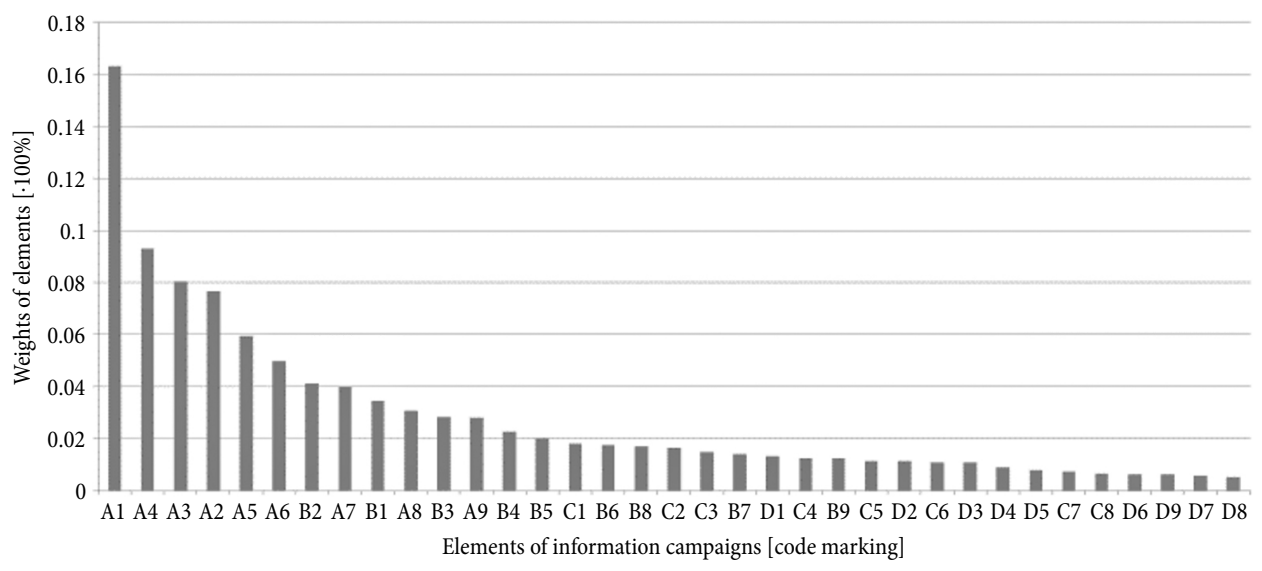

Fig. 2. Weights of importance reached in the way of Saaty's Method (two-level consideration)

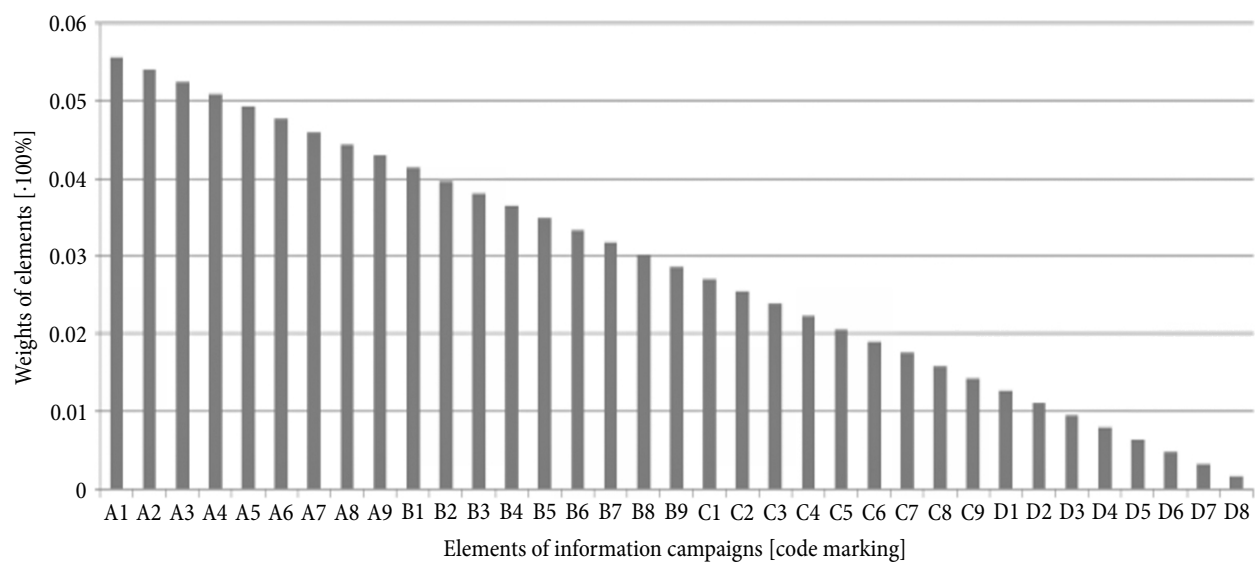

Fig. 3. Weights of importance reached in the way of Method of Order 
Table 2. UPT websites scores (overview)

\begin{tabular}{ccc}
\hline \multirow{2}{*}{$\begin{array}{c}\text { Category of city (after } \\
\text { number of inhabitants) }\end{array}$} & \multicolumn{2}{c}{ UPT websites score } \\
\cline { 2 - 3 } & average & median \\
\hline$\leq 99999$ & 0.3535 & 0.3838 \\
\hline $100000-499999$ & 0.5613 & 0.5726 \\
\hline $500000-999999$ & 0.5393 & 0.5233 \\
\hline $1000000-1999999$ & 0.4678 & 0.5139 \\
\hline$\geq 2000000$ & 0.4578 & 0.4561 \\
\hline
\end{tabular}

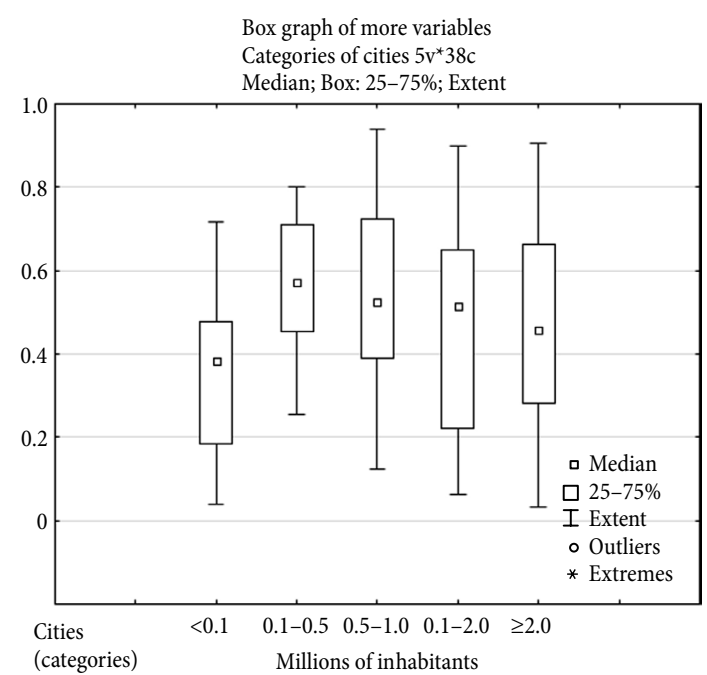

Fig. 4. Scores of UPT websites after size of cities (source: authors by using of sw. STATISTICA 12)

As follows from Table 2 and Tables A1-A5 (located in Appendix) as well as from Fig. 5 there is no important relation between score of UPT websites and size of the city.

It must be stated that this result is appropriate. It is able to be presupposed that information demands of UPT passengers are not directly depended on the city size also in reality.

Exception can be the first category (towns and cities under 99999 inhabitants). This fact is corresponding also with (Morrison 2007). Total average of scores is 0.4765 (median 0.4859). It can be stated that 'common' UPT websites are providing about $50 \%$ of information potential possible and there is able to find possibilities for quality improvement.

Medians of UPT websites scores after countries are on Fig. 6. Countries with 4 and more considered UPT systems (cities) are taken into consideration.

\section{Hypothesis}

Flexible service must be provided by UPT websites. For that reason, the main research hypothesis is focused on relation between extent of provided information and time of connection searching by passenger (not time of technical accessing to databases, etc.). Extent of provided information is expressed by the scores of UPT websites. The hypothesis is: 'Connection searching time is related to information extent in a negative way'.

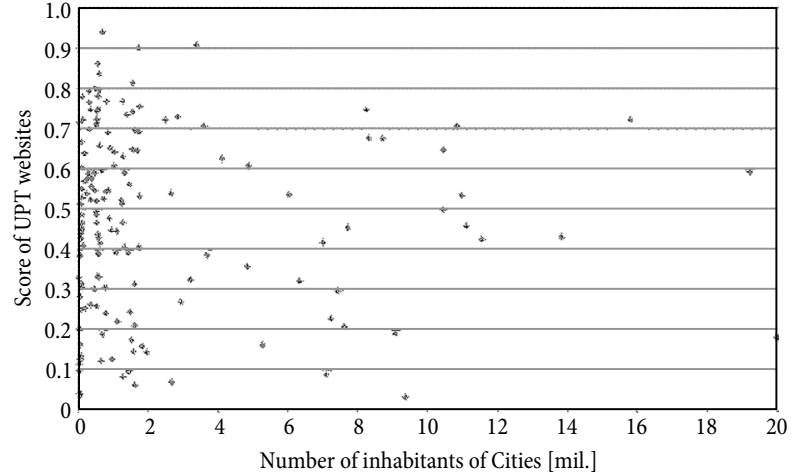

Fig. 5. Relation between number of inhabitants on city and UPT websites scores

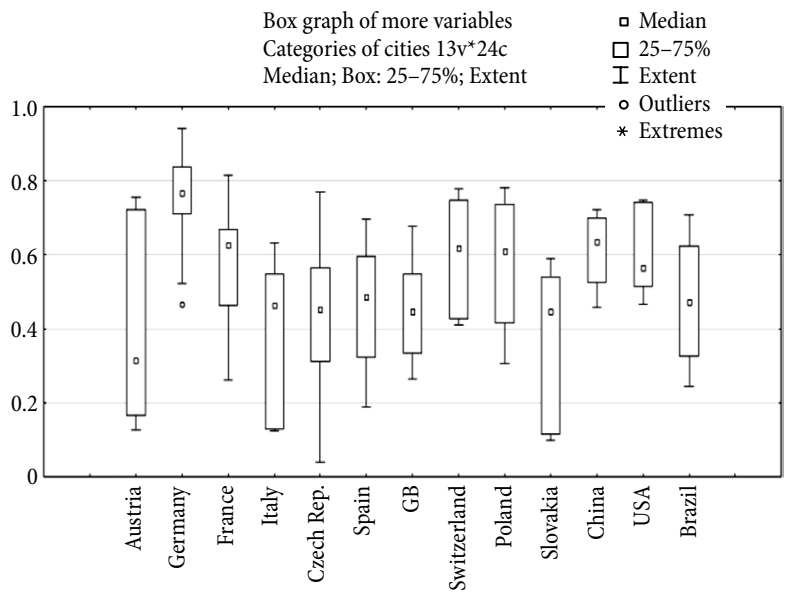

Fig. 6. Medians of UPT websites scores after countries (source: authors by using of sw. STATISTICA 12)

It means that shorter values of searching time can be reached by using websites with better quality level (broader extent of provided information, better score).

Test of this hypothesis is based on two pillars. The first is scoring of websites mentioned in Chapter 9.

The second pillar is customer test. Searching times were measured by for 60 UPT connections in 30 cities or towns of the Czech Republic and Slovakia. It was focused on these two countries only due to ensuring of the same conditions by test. Following biases influencing searching time can be replaced in this way: possible language barrier by fictive customers - passengers; different level of general knowledge about situation in local Internet as well as about the common conditions of UPT operating, etc.

Two connections were found in each UPT system. The task was very general. Connections were found between objects occurring in the most of cities or towns. The first connection was found between main railway station and the main seat of municipality (e.g. historical town hall), the second connection between the main square (city centre) and the main object of hospital.

Additional requirements for information were added due to complex evaluation. The first connection was equipped by information about fare and fare collection system (where it is possible to buy tickets, which 
kind of a ticket is necessary, how to access a vehicle - by which door, how to validate a ticket). This was representing a case, when passenger is using that UPT system for the first time. The second connection was equipped by requirement for barrier-free connection (low-floor vehicles) and information about fare for handicapped (disabled) passengers. It was representing searching in the case that passenger is more familiar with using of websites (previous experience with the first connection).

Fig. 7 represents relation between extent of provided information (expressed by score of websites) and searching times (total times for both connections in each town or city). Individual values are equipped by curve illustrating the relation. This curve has no meaning from the mathematical point of view (it is no function).

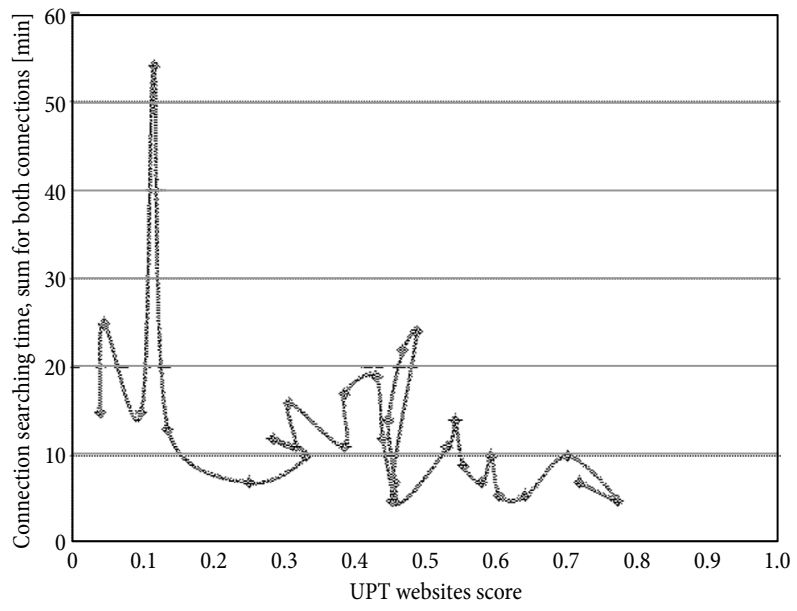

Fig. 7. Relation between score of websites and searching time

The hypothesis has been tested by the Pearson correlation coefficient. Value of the coefficient is $r=-0.50$. It can be characterized as a middle correlation.

This result is able to be interpreted that there is relation (dependence) between score of websites and times of connection searching. The middle correlation is in consonance with the fact that not all information estimated by scoring is necessary to be used by searching of given connections. On the other hand, positive impact of improving quality level of websites is able to be seen.

\section{Research Continuation}

These results will be used also in next continuation of this research. This research will be focused on detail determination of standards for information content of UPT websites. As follows from the Chapters mentioned above, it is not possible to determine these standards for all modes of transport (railway, road - bus, waterway) in the unified way. These standards for information content of websites must be designed individually for each transport mode as well as for integration of these modes in regions (integrated public passenger transport systems or transport associations). Also, standards of websites content for other transport modes than UPT are able to be solved in reduced form in the frame of this research.
The mark 'Passenger Friendly Web' is proposed to be used as 'commercial' name for this standardisation. These standards of information content of UPT websites will be divided into some categories. The lowest category will be the basic category. This category can be used as basic obligation for websites of all UPT systems. Next to this category, not-displayed on websites (no logo, etc.), there can be another three advanced categories - 'Passenger Friendly Web' of 3rd, 2nd, 1st Class. The 1st Class will be the most advanced category requiring fulfilling the highest number of requirements (elements) in as most qualitative way as possible. Each category can have own logo able to be placed (displayed) on the websites as a mark of quality. Displaying of logo can be considered as prestigious by UPT operators. Proposals of logo designs are placed on the Fig. 8. Logo will be coloured bronze, silver and gold for each of 'advanced' (3rd - 1st Class) categories for support of effect that it is an award for quality.

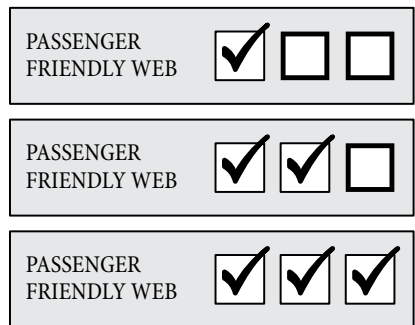

Fig. 8. Proposal of logo for 'Passenger Friendly Web' of 3rd-1st Class categories (bronze-silver-gold)

Websites of each category must naturally fulfil all basic and obligatory requirements and for awarding by 3rd, 2nd or 1st Class of 'Passenger Friendly Web' category must reach defined score for defined 'additional' information content. Extent of obligatory information elements as well as scale elements will be strictly determined after deep analysis connected to future research. Table 3 represents proposal of obligatory information elements for fulfilling of 3rd-1st Class categories. Elements are expressed by codes introduced in Chapter 7 .

Table 3. 'Passenger Friendly Web' - obligatory elements

\begin{tabular}{ll}
\hline \multicolumn{1}{c}{ Class } & \multicolumn{1}{c}{ Proposal of obligatory elements } \\
\hline 3rd - bronze & A1, A2, A3, A5-A9 \\
\hline 2nd - silver & A4, B1-B5, B7, C1 + all for 3rd Class \\
\hline 1st - gold & $\begin{array}{l}\text { B6, B8, B9, C2-C4, C7, D3 + all required } \\
\text { for 3rd and 2nd Class }\end{array}$ \\
\hline
\end{tabular}

Final structure of required information elements can be changed after results of future research. Minimal scores can be also determined in future research. These values can be higher than sum of weights of obligatory information elements mentioned in Table 3. It means that websites awarded by 'Passenger Friendly Web' of 3rd-1st Class will contain also others than obligatory information elements (Table 3) for score limit fulfilment. 
Score limits will also reflect state-of-the-art average values with motivation tendency for quality improvement (websites awarded by 3rd-1st Class of 'Passenger Friendly Web' must be over average).

It will be also connected to different conditions in each category, to different requirements of each group of passengers. Local specifics (for individual UPT systems) will be regarded as well. The proposal of this evaluation process exists now, but it is know-how of research team for possible project proposal (Chapter 12). This is the reason for what details are not able to be mentioned in this paper.

\section{Results Application}

Positive impact of application of research results is able to be seen by passengers (improved information for their decision to use UPT) first of all. On the other hand, positive impacts are also able to be reached for subjects funding UPT service (increased utilizing of paid transport supply), for transport operators or public passenger transport coordinators (reduction of decreasing tendency of passenger numbers), for society as well as for environment (higher rate of modal split for UPT). It is able to be summarized that some positive effects are able to be found by all subjects participating on UPT operation.

This theme is actual and important especially due to rising utilizing of websites as well as other electronic information sources (like applications designed for smart phones, etc.). It is also able to be presupposed that this tendency will be continued in the future. There is no information about similar attempt of systematic, detailed and complex research focused strictly on UPT in the field of content of provided information by electronic sources (websites) in the Czech Republic as well as abroad.

It has to be pointed out that the quality of provided information service about UPT (or public passenger transport in general) is also more and more important. It is connected to rising number of differences in tariffs, ticket types, application of smart cards (and different check-in/out or fare collecting systems) as well as to different operational conditions (e.g. boarding by first or by all vehicle doors) in individual UPT systems (cities). The general knowledge about UPT-using (making travelling more simply) is reduced due to these mentioned facts and it must be replaced by information service provided on as the best quality level as possible. General knowledge about UPT is also decreasing by rising modal share of individual car transport as well as cyclist transport in city areas.

The results presented in this paper are documenting, how it is possible to objectivize the evaluation of design (content) of Internet presentations (websites) or other electronic information sources with support of mathematical methods and procedures.

The research team is going to develop a proposal of research project for the Ministry of Transport of the Czech Republic or for some fund of the European
Union with the aim to create a methodology for setting of standards for information content of websites (electronic information sources), not only for UPT, but for all modes of public passenger transport. Vision of methodology utilization is that these requirements will able to be obligatory after application of this methodology in practice. Decision about public transport operation licencing can be obligated by ensuring of information service on required quality level. These conditions are generally set by the Ministry of Transport (in the legislative way). There is mentioned application in the Czech Republic only due to fact that it must be implemented into concrete legal framework of UPT. On the other hand, it is able to be presupposed that similar way of results implementing (according to local legal framework) is able in any other country.

In the case that the results of proposed project will be applied, it will be necessary to create a subject for supervising of websites information content (presumption for transport service licence) and for awarding by 3rd-1st Class of 'Passenger Friendly Web'. Awarding by 3rd-1st Class is also able to be seen as possible competitive advantage for transport operators in public competition. For that reason, it is able to be presupposed that the awarding by 3rd-1st Class of 'Passenger Friendly Web' is able to be a commercial service. It will be paid by transport operators from their own sources (not by using of public sources).

\section{Conclusions}

The research objective: 'Internet presentations of UPT are not created on the best quality level and with the highest explanatory power as possible (with regard to costs and other limitations)' has not been disproved. It has been confirmed by the analysis made in different countries that not all possibilities how to provide the most of required information (on the best quality level) are utilized.

Research hypothesis 'Connection searching time is related to information extent in a negative way' has not been rejected as well.

Information service is an important element of UPT in any operation conditions. No matter in what city or country UPT operated is, all services must be wellpromoted and passengers well-informed. It is a mistake to presuppose that e.g. UPT system in a little city does not need information service, because every daily-user (member of Group 1 of passengers) knows everything. What about passengers (like city visitors - Group 3) who do not know that system and they are not finding for this service. Operational information is essential for all passengers. On the other hand, ensuring of quality information service will generate costs and care will be needed (e.g. employees preparing content of websites, software tools, etc.).

Weight (importance) of each element of websites is evaluated for these reasons in this paper. Points of view of all typical groups of UPT passengers are regarded in the paper. 
Internet websites presentations are mentioned as the basic electronic information sources creating base for all possible electronic sources.

On the other hand, development of information technologies (smart phones, new devices of information systems, new ways of information transfer, etc.) provides also a field for future research of this theme. UPT must be 'visible' and 'involved' in this tendency for attracting of passengers also in this 'digital future'. Description and evaluation of meaning and importance of individual information elements is a basic precondition for appropriate using of information tools. It must be also stated that websites are usually not used in an appropriate and suitable way as follows from mentioned analysis of practice. It is also evidence that this is an actual theme. A proposed way, how transport operators and other responsible institutions are able to be motivated to fulfil proposed quality standards of information service provided by websites, is also mentioned in the final part of paper.

UPT is one part of transport only. Authors are recommending similar analysis also for other passenger transport modes (railway, suburban or long-distance bus, air transport). It must be realized in an independent way. The reason is that there are different groups of passengers with different information and transport needs. Reservation system is able to be mentioned as illustrative example. It is very common and may be an essential tool e.g. in air passenger transport, but in 'operative' UPT system it can be ineffective or sometimes also impossible to realize. Due to this and similar facts this model of websites evaluation is able to be transferred to other transport modes on general level only. Set of individual information elements and their importance must be determined independently.

\section{Acknowledgements}

This paper was published with the support of the project 'Support of short term attachments and skilful activities for innovation of tertiary education at the Jan Perner Transport Faculty and Faculty of Electrical Engineering and Informatics, University of Pardubice, registration No. CZ.1.07/2.4.00/17.0107', in the tutor team 'Transport Service in Region'.

\section{References}

Caulfield, B.; O’Mahony, M. 2007. An examination of the public transport information requirements of users, IEEE Transactions on Intelligent Transportation Systems 8(1): 21-30. http://dx.doi.org/10.1109/TITS.2006.888620

Cheng, Y.-H. 2011. Evaluating web site service quality in public transport: evidence from Taiwan high speed rail, Transportation Research Part C: Emerging Technologies 19(6): 957974. http://dx.doi.org/10.1016/j.trc.2011.04.003

Crainic, T. G.; Gendreau, M.; Potvin, J.-Y. 2009. Intelligent freight-transportation systems: assessment and the contribution of operations research, Transportation Research Part C: Emerging Technologies 17(6): 541-557. http://dx.doi.org/10.1016/j.trc.2008.07.002
ČSN EN 13816:2003. Doprava - Logistika a služby - Veřejná přeprava osob - Definice jakosti služby, cíle a měřní. (in Czech).

ČSN EN 15140:2007. Veřejná přeprava osob - Základní požadavky a doporučení pro systémy hodnocení kvality poskytované služby (in Czech).

Dell'Olio, L.; Ibeas, A.; Cecin, P. 2011. The quality of service desired by public transport users, Transport Policy 18(1): 217-227. http://dx.doi.org/10.1016/j.tranpol.2010.08.005

EDITS. 2013. The Central Europe Project EDITS (European Digital Traffic Infrastructure Network for Intelligent Transport Systems). AustriaTech - Federal Agency for technological Measures Ltd. Available from Internet: http://www.central2013.eu/nc/central-projects/approved-projects/fundedprojects/?tx_fundedprojects_pi $1 \% 5$ Bproject $\% 5 \mathrm{D}=120$

EN 13816:2002 - Transportation. Logistics and Services. Public Passenger Transport. Service Quality Definition, Targeting and Measurement.

EN 15140:2006. Public Passenger Transport. Basic Requirements and Recommendations for Systems that Measure Delivered Service Quality.

Hasan, L.; Abuelrub, E. 2011. Assessing the quality of web sites, Applied Computing and Informatics 9(1): 11-29. http://dx.doi.org/10.1016/j.aci.2009.03.001

IDOS $^{\text {TM }}$ 2014. Nation-Wide Information System of Timetables. Ministry of Transport of the Czech Republic. Available from Internet: http://jizdnirady.idnes.cz/vlakyautobusymhdvse/spojeni (in Czech).

Kolosz, B.; Grant-Muller, S.; Djemame, K. 2013. Modelling uncertainty in the sustainability of intelligent transport systems for highways using probabilistic data fusion, Environmental Modelling \& Software 49: 78-97. http://dx.doi.org/10.1016/j.envsoft.2013.07.011

KORDIS JMK, a.s. 2014. Brno - Interactive Transport Map. SmartGIS. Available from Internet: http://brno.planydopravy.cz (in Czech).

Mahmoud, M.; Hine, J. 2013. Using AHP to measure the perception gap between current and potential users of bus services, Transportation Planning and Technology 36(1): 4-23. http://dx.doi.org/10.1080/03081060.2012.745316

Matuška, J. 2010. The methodology for designing accessible public transportation: ehe Czech experience, Transport 25(2): 222-228. http://dx.doi.org/10.3846/transport.2010.27

Molin, E. J. E.; Timmermans, H. J. P. 2006. Traveler expectations and willingness-to-pay for Web-enabled public transport information services, Transportation Research Part C: Emerging Technologies 14(2): 57-67. http://dx.doi.org/10.1016/j.trc.2006.05.003

Monzon, A.; Hernandez, S.; Cascajo, R. 2013. Quality of bus services performance: benefits of real time passenger information systems, Transport and Telecommunication 14(2): 155-166. http://dx.doi.org/10.2478/ttj-2013-0013

Morrison, A. 2007. The geospatial content of public transport websites for 60 localities worldwide, Journal of Maps 3(1): 1-19. http://dx.doi.org/10.1080/jom.2007.9710823

Multi-Criteria Analysis: a Manual. 2009. London, Department for Communities and Local Government. 168 p. Available from Internet: https://www.gov.uk/government/uploads/ system/uploads/attachment_data/file/7612/1132618.pdf

Ragsdale, C. T. 2011. Managerial Decision Modeling. Thomson South-Western. $816 \mathrm{p}$.

Saaty, T. L.; Vargas, L. G. 2013. Decision Making with the Analytic Network Process: Economic, Political, Social and Technological Applications with Benefits, Opportunities, Costs and Risks. 363 p. http://dx.doi.org/10.1007/978-1-4614-7279-7 
Saaty, T. L. 1980. The Analytic Hierarchy Process. McGraw-Hill. $287 \mathrm{p}$.

Tyrinopoulos, Y. 2011. Integrating vehicle positioning data in quality control programs in public transit: a European perspective, Transportation Planning and Technology 34(2): 167-176. http://dx.doi.org/10.1080/03081060.2011.554711

Vlassenroot, S.; Brookhuis, K.; Marchau, V.; Witlox, F. 2010. Towards defining a unified concept for the acceptability of intelligent transport systems (ITS): a conceptual analysis based on the case of intelligent speed adaptation (ISA), Transportation Research Part F: Traffic Psychology and Behaviour 13(3): 164-178.

http://dx.doi.org/10.1016/j.trf.2010.02.001

Xu, B.; Chen, X.; Lin, H.; Yang, C. 2013. Decision oriented intelligent transport information platform design research case study of Hangzhou City, Procedia - Social and Behavioral Sciences 96: 2230-2239.

http://dx.doi.org/10.1016/j.sbspro.2013.08.252

Yatskiv, I.; Kopytov, E.; Casellato, D.; Luppino, G.; McDonald, R. 2013. Benchmarking and assessment of good practices in public transport information systems, Transport and Telecommunication 14(4): 325-336.

http://dx.doi.org/10.2478/ttj-2013-0028

\section{APPENDIX}

\section{UPT Websites Scores}

Table A1. UPT websites scores

(cities under 100000 inhabitants)

\begin{tabular}{lccc}
\hline \multicolumn{1}{c}{ City (town) } & $\begin{array}{c}\text { Country } \\
\text { code }\end{array}$ & $\begin{array}{c}\text { Number of } \\
\text { inhabitants } \\
\text { [mil. inhabit. }\end{array}$ & $\begin{array}{c}\text { UPT } \\
\text { websites } \\
\text { score }\end{array}$ \\
\hline Mariánské Lázně & $\mathrm{CZ}$ & 0.01 & 0.3302 \\
\hline Havlíčkův Brod & $\mathrm{CZ}$ & 0.02 & 0.2034 \\
\hline Ždár nad Sázavou & $\mathrm{CZ}$ & 0.02 & 0.7154 \\
\hline Púchov & $\mathrm{SK}$ & 0.02 & 0.1144 \\
\hline Stará Ĺubovňa & $\mathrm{SK}$ & 0.02 & 0.0972 \\
\hline Mladá Boleslav & $\mathrm{CZ}$ & 0.04 & 0.2823 \\
\hline Třebíč & $\mathrm{CZ}$ & 0.04 & 0.0436 \\
\hline Povážská Bystrica & $\mathrm{SK}$ & 0.04 & 0.3836 \\
\hline Karlovy Vary & $\mathrm{CZ}$ & 0.05 & 0.0386 \\
\hline Děčín & $\mathrm{CZ}$ & 0.05 & 0.4378 \\
\hline Jihlava & $\mathrm{CZ}$ & 0.05 & 0.4278 \\
\hline Teplice & $\mathrm{CZ}$ & 0.05 & 0.2488 \\
\hline Chomutov & $\mathrm{CZ}$ & 0.05 & 0.4551 \\
\hline Přrov & $\mathrm{CZ}$ & 0.05 & 0.3840 \\
\hline Dornbirn & $\mathrm{A}$ & 0.05 & 0.1650 \\
\hline Opava & $\mathrm{CZ}$ & 0.06 & 0.5127 \\
\hline Wels & $\mathrm{A}$ & 0.06 & 0.1267 \\
\hline Most & $\mathrm{CH}$ & 0.07 & 0.3058 \\
\hline Luzern & 0.07 & 0.6673 \\
\hline St. Gallen & 0.07 & 0.4272 \\
\hline Zlín & 0.08 & 0.3152 \\
\hline
\end{tabular}

\begin{tabular}{llll}
\hline Bánská Bystrica & SK & 0.08 & 0.1347 \\
\hline Hradec Králové & $\mathrm{CZ}$ & 0.09 & 0.4859 \\
\hline České Budějovice & $\mathrm{CZ}$ & 0.09 & 0.5513 \\
\hline Ústí nad Labem & $\mathrm{CZ}$ & 0.09 & 0.4666 \\
\hline Pardubice & $\mathrm{CZ}$ & 0.09 & 0.6028 \\
\hline Prešov & $\mathrm{SK}$ & 0.09 & 0.4462 \\
\hline Žilina & SK & 0.09 & 0.5297 \\
\hline \multicolumn{4}{l}{ Score: average $0.3535 ;$ median 0.3838} \\
\hline
\end{tabular}

Table A2. UPT websites scores (cities with 100000-499999 inhabitants)

\begin{tabular}{lccc}
\hline \multicolumn{1}{c}{ City (town) } & $\begin{array}{c}\text { Country } \\
\text { code }\end{array}$ & $\begin{array}{c}\text { Number of } \\
\text { inhabitants } \\
\text { [mil. inhabit. }\end{array}$ & $\begin{array}{c}\text { UPT } \\
\text { websites } \\
\text { score }\end{array}$ \\
\hline Olomouc & CZ & 0.10 & 0.4516 \\
\hline Liberec & CZ & 0.10 & 0.4543 \\
\hline Klagenfurt & $\mathrm{A}$ & 0.10 & 0.3142 \\
\hline Bern & $\mathrm{CH}$ & 0.12 & 0.7788 \\
\hline Innsbruck & $\mathrm{A}$ & 0.12 & 0.7226 \\
\hline Lausanne & $\mathrm{CH}$ & 0.13 & 0.4092 \\
\hline Plzeň & $\mathrm{CZ}$ & 0.17 & 0.6400 \\
\hline Genf & $\mathrm{CH}$ & 0.18 & 0.5686 \\
\hline Linz & $\mathrm{A}$ & 0.19 & 0.2552 \\
\hline Košice & $\mathrm{SK}$ & 0.24 & 0.5398 \\
\hline Graz & $\mathrm{A}$ & 0.27 & 0.5767 \\
\hline Newcastle u.t. & $\mathrm{GB}$ & 0.28 & 0.5894 \\
\hline Ostrava & $\mathrm{CZ}$ & 0.30 & 0.6987 \\
\hline Münster & $\mathrm{D}$ & 0.30 & 0.7655 \\
\hline Karlsruhe & $\mathrm{D}$ & 0.30 & 0.7949 \\
\hline Wuppertal & $\mathrm{D}$ & 0.34 & 0.5234 \\
\hline Zurich & $\mathrm{CH}$ & 0.35 & 0.7478 \\
\hline Cardiff & $\mathrm{GB}$ & 0.35 & 0.2626 \\
\hline Bochum & $\mathrm{D}$ & 0.36 & 0.5571 \\
\hline Brno & $\mathrm{CK}$ & 0.38 & 0.5782 \\
\hline Bratislava & 0.46 & 0.5912 \\
\hline Liverpool & $\mathrm{GB}$ & 0.47 & 0.3027 \\
\hline Leeds & 0.47 & 0.5480 \\
\hline Duisburg & 0.49 & 0.8003 \\
\hline
\end{tabular}

Table A3. UPT Websites Scores (cities with 500000-999999 inhabitants)

\begin{tabular}{lccc}
\hline City (town) & $\begin{array}{c}\text { Country } \\
\text { code }\end{array}$ & $\begin{array}{c}\text { Number of } \\
\text { inhabitants } \\
\text { [mil. inhabit. }\end{array}$ & $\begin{array}{c}\text { UPT } \\
\text { websites } \\
\text { score }\end{array}$ \\
\hline Nürnberg & D & 0.50 & 0.7112 \\
\hline Hannover & D & 0.51 & 0.7243 \\
\hline Douai-Lens & F & 0.51 & 0.2600 \\
\hline Manchester & GB & 0.51 & 0.4942 \\
\hline Antwerpen & $\mathrm{B}$ & 0.51 & 0.4885 \\
\hline
\end{tabular}




\begin{tabular}{|c|c|c|c|}
\hline Leipzig & $\mathrm{D}$ & 0.52 & 0.4652 \\
\hline Lisabon & $\mathrm{P}$ & 0.52 & 0.5210 \\
\hline Dresden & $\mathrm{D}$ & 0.53 & 0.7139 \\
\hline Dublin & IE & 0.53 & 0.3330 \\
\hline Göteborg & $\mathrm{S}$ & 0.53 & 0.7441 \\
\hline Bremen & $\mathrm{D}$ & 0.55 & 0.8627 \\
\hline Poznań & $\mathrm{PL}$ & 0.55 & 0.7801 \\
\hline Sheffield & GB & 0.56 & 0.4378 \\
\hline Vilnius & LT & 0.56 & 0.3914 \\
\hline Dortmund & $\mathrm{D}$ & 0.57 & 0.7808 \\
\hline Essen & $\mathrm{D}$ & 0.57 & 0.7485 \\
\hline Málaga & $\mathrm{E}$ & 0.57 & 0.4289 \\
\hline Venezia & $\mathrm{I}$ & 0.58 & 0.3883 \\
\hline Düsseldorf & $\mathrm{D}$ & 0.59 & 0.8375 \\
\hline Stuttgart & $\mathrm{D}$ & 0.60 & 0.7962 \\
\hline Glasgow & GB & 0.60 & 0.3333 \\
\hline Helsinki & FIN & 0.61 & 0.6573 \\
\hline Rotterdam & NL & 0.62 & 0.4156 \\
\hline Palermo & $\mathrm{I}$ & 0.65 & 0.1232 \\
\hline Zaragoza & $\mathrm{E}$ & 0.68 & 0.5967 \\
\hline Frankfurt a. Main & $\mathrm{D}$ & 0.69 & 0.9409 \\
\hline Sevilla & $\mathrm{E}$ & 0.70 & 0.1889 \\
\hline Łódź & $\mathrm{PL}$ & 0.72 & 0.5256 \\
\hline Kraków & $\mathrm{PL}$ & 0.76 & 0.3068 \\
\hline Valencia & $\mathrm{E}$ & 0.79 & 0.5442 \\
\hline Zagreb & HR & 0.79 & 0.2415 \\
\hline Amsterdam & NL & 0.80 & 0.7683 \\
\hline Bordeaux & $\mathrm{F}$ & 0.84 & 0.6905 \\
\hline Turino & $\mathrm{I}$ & 0.87 & 0.5471 \\
\hline Toulouse & $\mathrm{F}$ & 0.88 & 0.4770 \\
\hline Stockholm & $\mathrm{S}$ & 0.90 & 0.6519 \\
\hline Nice & $\mathrm{F}$ & 0.94 & 0.4477 \\
\hline Napoli & $\mathrm{I}$ & 0.96 & 0.1279 \\
\hline \multicolumn{4}{|c|}{ Score: average 0.5393 ; median 0.5233} \\
\hline
\end{tabular}

\begin{tabular}{|c|c|c|c|}
\hline Montevideo & UY & 1.27 & 0.0824 \\
\hline San Diego & USA & 1.27 & 0.4655 \\
\hline Auckland & NZ & 1.32 & 0.5912 \\
\hline Córdoba & $\mathrm{E}$ & 1.32 & 0.4069 \\
\hline München & $\mathrm{D}$ & 1.39 & 0.7361 \\
\hline Novosibirsk & RUS & 1.42 & 0.3918 \\
\hline Almaty & $\mathrm{KZ}$ & 1.44 & 0.0963 \\
\hline Philadelphia & USA & 1.45 & 0.5633 \\
\hline Recife & $\mathrm{BR}$ & 1.48 & 0.2443 \\
\hline Quito & $\mathrm{EC}$ & 1.52 & 0.1738 \\
\hline Lyon & $\mathrm{F}$ & 1.55 & 0.8138 \\
\hline Phoenix & USA & 1.55 & 0.7421 \\
\hline Marseille & $\mathrm{F}$ & 1.56 & 0.6485 \\
\hline Manila & $\mathrm{RP}$ & 1.57 & 0.1468 \\
\hline Barcelona & E & 1.61 & 0.6970 \\
\hline Rabat & MA & 1.62 & 0.2120 \\
\hline Montreal & CAN & 1.62 & 0.3145 \\
\hline Pretoria & $\mathrm{ZA}$ & 1.62 & 0.0627 \\
\hline Brisbane & AUS & 1.68 & 0.6462 \\
\hline Warszawa & PL & 1.72 & 0.6916 \\
\hline Curitiba & $\mathrm{BR}$ & 1.72 & 0.4069 \\
\hline Hamburg & $\mathrm{D}$ & 1.73 & 0.8999 \\
\hline Wien & A & 1.74 & 0.7551 \\
\hline Budapest & $\mathrm{H}$ & 1.74 & 0.5327 \\
\hline Caracas & YV & 1.82 & 0.1603 \\
\hline Meddelín & $\mathrm{CO}$ & 1.96 & 0.1446 \\
\hline \multicolumn{4}{|c|}{ Score: average 0.4678 ; median 0.5139} \\
\hline
\end{tabular}

Table A5. UPT websites scores

Table A4. UPT websites Scores (cities: 1000000-1999999 inhabitants)

\begin{tabular}{lccc}
\hline City (town) & $\begin{array}{c}\text { Country } \\
\text { code }\end{array}$ & $\begin{array}{c}\text { Number of } \\
\text { inhabitants } \\
\text { [mil. inhabit. }\end{array}$ & $\begin{array}{c}\text { UPT } \\
\text { websites } \\
\text { score }\end{array}$ \\
\hline Köln & D & 1.02 & 0.6424 \\
\hline Lille & F & 1.02 & 0.6074 \\
\hline Bruxelles & BE & 1.07 & 0.3935 \\
\hline Birmingham & GB & 1.09 & 0.4456 \\
\hline Belgrad & SRB & 1.11 & 0.2218 \\
\hline Perth & AUS & 1.23 & 0.5230 \\
\hline Dallas & USA & 1.24 & 0.5139 \\
\hline Milano & I & 1.26 & 0.6311 \\
\hline Praha & CZ & 1.27 & 0.7697 \\
\hline
\end{tabular}

(cities: 2000000 inhabitants and more)

\begin{tabular}{lccc}
\hline City (town) & $\begin{array}{c}\text { Country } \\
\text { code }\end{array}$ & $\begin{array}{c}\text { Number of } \\
\text { inhabitants } \\
\text { [mil. inhabit. }\end{array}$ & $\begin{array}{c}\text { UPT } \\
\text { websites } \\
\text { score }\end{array}$ \\
\hline Toronto & CAN & 2.50 & 0.7222 \\
\hline Roma & I & 2.64 & 0.5391 \\
\hline Kyiv & UA & 2.66 & 0.0699 \\
\hline Chicago & USA & 2.84 & 0.7301 \\
\hline Casablanca & MA & 2.93 & 0.2697 \\
\hline Madrid & E & 3.21 & 0.3245 \\
\hline Berlin & D & 3.38 & 0.9064 \\
\hline Singapore & SGP & 3.58 & 0.7072 \\
\hline Busan & ROK & 3.68 & 0.3856 \\
\hline Melbourne & AUS & 4.10 & 0.6251 \\
\hline Santiago de Chile & RCH & 4.84 & 0.3585 \\
\hline Sankt Petersburg & RUS & 4.88 & 0.6072 \\
\hline Bengalore & IND & 5.28 & 0.1638 \\
\hline Rio de Janeiro & BR & 6.02 & 0.5363 \\
\hline Bogotá & CO & 6.32 & 0.3209 \\
\hline Hongkong & HK & 7.01 & 0.4173 \\
\hline & & & \\
\hline
\end{tabular}




\begin{tabular}{lccc}
\hline City (town) & $\begin{array}{c}\text { Country } \\
\text { code }\end{array}$ & $\begin{array}{c}\text { Number of } \\
\text { inhabitants } \\
\text { [mil. inhabit. }\end{array}$ & $\begin{array}{c}\text { UPT } \\
\text { websites } \\
\text { score }\end{array}$ \\
\hline Lahore & PK & 7.09 & 0.0900 \\
\hline Bangkok & T & 7.23 & 0.2280 \\
\hline Cairo & ET & 7.42 & 0.2965 \\
\hline Lima & PE & 7.61 & 0.2084 \\
\hline Tehran & IT & 7.71 & 0.4539 \\
\hline New York & USA & 8.24 & 0.7468 \\
\hline London & GB & 8.31 & 0.6770 \\
\hline Shenzhen & PRC & 8.70 & 0.6756 \\
\hline Tokio & J & 9.07 & 0.1915 \\
\hline Lagos & RN & 9.35 & 0.0329 \\
\hline Seoul & ROK & 10.43 & 0.4986 \\
\hline Paris & F & 10.46 & 0.6471 \\
\hline São Paulo & BR & 10.83 & 0.7082 \\
\hline Delhi & IND & 10.97 & 0.5339 \\
\hline Guanghzou & PRC & 11.11 & 0.4583 \\
\hline Moskva & RUS & 11.55 & 0.4249 \\
\hline Istanbul & PRC & 13.82 & 0.4303 \\
\hline Beijing & MEX & 19.98 & 0.7218 \\
\hline Shanghai & & & 0.5921 \\
\hline Mexico City & median 0.4561 & \\
\hline Score: average 0.457814 \\
\hline
\end{tabular}

